\title{
Cell-mediated and humoral immune responses to aspermatogenic antigen in experimental allergic orchitis in the guinea-pig
}

\author{
A. L. Meng and K. S. K. Tung \\ Department of Pathology, University of New Mexico, Albuquerque, New Mexico 87131, U.S.A.
}

\begin{abstract}
Summary. Guinea-pigs were immunized with a defined and highly potent aspermatogenic antigen, $\mathrm{G} 75 \mathrm{~m}$, and the occurrence of orchitis was correlated with (1) cellmediated immune responses to $\mathrm{G} 75 \mathrm{~m}$, determined by lymph node cell proliferation and by secretion of macrophage migration inhibitory factor (MIF) by peritoneal exudate cells, and (2) humoral antibodies to $\mathrm{G75m}$ and to cell surface antigens of guinea-pig testicular cells, by radioimmunometric assays. A consistent temporal relationship between cell-mediated immune responses and disease was found: lymph node cell proliferation was positive by Day 4, followed 3 days later by maximum secretion of MIF, and orchitis lesions were manifest on Day 10. In contrast, maximal IgG antibodies to $\mathrm{G} 75 \mathrm{~m}$ or to the surface antigens of spermatozoa/testicular cells were detected at a time when cell-mediated immune responses and active testicular lesions had subsided. In individual animals, lymph node cell proliferation increased with severity of orchitis, while MIF secretion by peritoneal cells increased with orchitis only late in the disease. Early in disease, MIF response showed a negative correlation with orchitis. Moreover, peritoneal injection of oil reduced the incidence of early lymph node cell proliferative responses, and delayed the onset of testicular disease. These findings are consistent with competition between different inflammatory sites for recently antigen-activated $T$ lymphocytes. We conclude that (1) the development of orchitis correlates with cell-mediated immune responses to purified aspermatogenic antigens but not with IgG antibody responses, and (2) when the same animal is used to assess different aspects of cellular immunity and autoimmune disease, one study may significantly influence the other.
\end{abstract}

\section{Introduction}

Since the first descriptions of experimental allergic orchitis (Voisin, Delaunay \& Barber, 1951; Freund, Lipton \& Thompson, 1953), studies of the immunopathology and pathogenesis of this disease have been based on crude extracts from guinea-pig testis or spermatozoa. Since sperm/testis autoantigens may not be aspermatogenic (i.e. may not induce allergic orchitis) (Hagopian, Limjuco, Jackson, Carlo \& Eylar, 1976), investigation of correlation between allergic orchitis and the immune responses to crude tissue extracts may yield misleading or confusing results. Several aspermatogenic proteins and glycoproteins from guinea-pig testis have been isolated and characterized (Jackson, Hagopian, Carlo, Limjuco \& Eylar, 1975, 1976; Hagopian, Jackson, Carlo, Limjuco \& Eylar, 1975; Hagopian et al., 1976). However, information on the development and progression of testicular lesions induced by these antigens is sparse (Hagopian et al., 1975; Carlo, 
Hagopian, Jackson, Limjuco \& Eylar, 1976). We have purified two aspermatogenic proteins, one from guinea-pig spermatozoa, named AP2 (Teuscher, Wild \& Tung, 1983a), and the other from guinea-pig testis, AP3 (Teuscher et al., 1983b). The physicochemical characteristics of these antigens are different from those of aspermatogenic antigens already described: AP2 is an acidic protein of $M_{r} 9500$, whereas AP3 is a basic protein $\left(M_{r} 12500\right)$ that retains aspermatogenic activity after reduction and alkylation. Since the yields of these antigens are low, it would be impractical and excessively costly to study in detail allergic orchitis induced by them.

During the purification of AP3, a preparation of proteins/glycoproteins of $M_{r} 12000-30000$, known as G75m, was found to be highly active in inducing allergic orchitis. We have therefore studied the histopathology of experimental allergic orchitis induced by G75m, and searched for relationships between the disease process and humoral and cell-mediated immune responses to G75m.

\section{Materials and Methods}

Animals

Adult male Hartley non-inbred guinea-pigs with a mean \pm s.d. body weight of $647 \pm 108 \mathrm{~g}$ $(\mathrm{N}=117)$ were purchased from Camm Research Institute, Inc. (Wayne, NJ).

\section{Isolation of aspermatogenic antigen, $\mathrm{G75m}$}

The purification steps were a modification of the method for isolation of the aspermatogenic antigen API (Jackson et al., 1975). Two batches of G75m antigen were used in our study, called pool A and pool B. Pool B antigen was prepared according to Teuscher et al. (1983b) and included the following steps: (1) homogenization of the testes, (2) lipid extraction, (3) acid extraction, (4) removal of materials that precipitate at $\mathrm{pH} 7$, (5) ammonium sulphate precipitation, (6) trichloroacetic acid precipitation and (7) Sephadex G75 column chromatography. In the preparation of pool A antigen, step 4 was omitted and, in step 5, ammonium sulphate was not dialysed. Antigen concentrations were assessed by absorbance at $280 \mathrm{~nm}$, assuming $1 \mathrm{mg} / \mathrm{ml}=$ 0.60 . Both pools consistently induced orchitis at $2-10 \mu \mathrm{g}$ per guinea-pig. The freeze-dried preparations of $\mathrm{G} 75 \mathrm{~m}$ were reconstituted with saline $(9 \mathrm{~g} \mathrm{NaCl} / \mathrm{l})$ to about $4 \mathrm{mg} / \mathrm{ml}$, filter-sterilized, and stored at $4^{\circ} \mathrm{C}$.

\section{Immunizations}

One volume of $\mathrm{G} 75 \mathrm{~m}$ was homogenized into 1 volume of Freund's complete adjuvant containing $0.5 \mathrm{mg}$ Mycobacterium tuberculosis H37Ra/ml (DIFCO, Detroit, MI). Each guinea-pig was immunized with $50 \mu \mathrm{g} \mathrm{G} 75 \mathrm{~m}$ in $0.2 \mathrm{ml}$, distributed among the four footpads. Control guineapigs were either unimmunized or immunized with Freund's complete adjuvant.

\section{Preparation of lymph node cells}

Guinea-pigs were exsanguinated by cardiac puncture under light ether anaesthesia. Subsequent work was done aseptically; materials and reagents were sterile, and kept on ice unless stated otherwise. Popliteal, superficial inguinal, axillary and subscapular lymph nodes were removed and placed in RPMI 1640 medium (GIBCO, Santa Clara, CA) with $10 \mathrm{mM}-\mathrm{Hepes}, 10$ units heparin/ml and $10 \mu \mathrm{g}$ DNAse/ml (Sigma, St Louis, MO), called Medium RHHD. Lymph nodes were minced in Medium RHHD, pressed through a 60-mesh stainless-steel sieve, filtered through nylon cloth (Nitex No. 110, TETCO, Inc., Elmsford, NY) and centrifuged at $300 \mathrm{~g}$ for $10 \mathrm{~min}$ at $10^{\circ} \mathrm{C}$. The lymph node cells were resuspended in $80 \mathrm{ml}$ Medium RHHD. To separate live from dead cells, each 
$20 \mathrm{ml}$ was layered onto $10 \mathrm{ml}$ hypaque-ficoll (Parish, Kirov, Bowern \& Blanden, 1974), without sodium azide at about $25^{\circ} \mathrm{C}$, and centrifuged at $1600 \mathrm{~g}$ for $15 \mathrm{~min}$ at $20-25^{\circ} \mathrm{C}$. The cells from the interface were washed twice with Medium RPMI $1640+10$ mM-Hepes before they were resuspended in the culture medium to $5 \times 10^{6}$ viable cells $/ \mathrm{ml}$. The culture medium was Medium RPMI 1640 with $10 \mathrm{mM}-$ Hepes, $100 \mu \mathrm{g}$ gentamycin $/ \mathrm{ml}$, and $10 \%$ heated-inactivated normal guineapig serum (Pel Freez, Rogers, AK).

\section{Preparation of peritoneal exudate cells}

These cells were harvested 3 days after stimulation with $20 \mathrm{ml}$ sterile mineral oil (Humco Lab, Texarkana, TX). After exsanguination and lavage of the peritoneal cavity, the cells were obtained by centrifugation at $500 \mathrm{~g}$ for $10 \mathrm{~min}$ at $10^{\circ} \mathrm{C}$, pooled and resuspended with $10-15 \mathrm{ml}$ lysing solution (Roos \& Loos, 1970) and kept on ice for exactly $5 \mathrm{~min}$ with periodic mixing. Peritoneal exudate cells were washed twice with Eagle's minimum essential medium (MEM) with Hanks' salts and glutamine, and resuspended in culture medium to $65 \times 10^{6} / \mathrm{ml}$. The culture medium was MEM with Earle's salts and glutamine (Flow Laboratories, Rockville, MD), $10 \mathrm{~mm}$-Hepes, $100 \mu \mathrm{g}$ gentamycin $/ \mathrm{ml}$, and $15 \%$ heat-inactivated serum from normal guinea-pigs; this serum pool had had lipids and aggregates removed by centrifugation. Only cells with a viability $>90 \%$ were used. Differential counts of peritoneal exudate cells stained with Giemsa consisted of $80-85 \%$ large mononuclear cells, 5-10\% smaller mononuclear cells, and neutrophils.

\section{In-vitro assays}

Lymph node cell. Antigen-initiated incorporation of $\left[{ }^{3} \mathrm{H}\right]$ thymidine by the lymph node cell was set up in microtitre plates (Flow Laboratories, Rockville, MD). Each well contained $100 \mu l$ of a dilution of $\mathrm{G} 75 \mathrm{~m}$ in culture medium and $100 \mu \mathrm{l}$ of lymph node cells $\left(5 \times 10^{5}\right)$. The plates were incubated for $24 \mathrm{~h}$ at $37^{\circ} \mathrm{C}$ in a humidified atmosphere of $5-6 \% \mathrm{CO}_{2}$ in air. Subsequently, the lymph node cells were pulsed with $0.5 \mu \mathrm{Ci}\left[{ }^{3} \mathrm{H}\right]$ thymidine (sp. act. $2 \mathrm{Ci} / \mathrm{mmol}$, Amersham Corp., Arlington Hts, IL), cultured for $24 \mathrm{~h}$, and collected with a MASH II cell harvester (Microbiological Associates, Walkersville, MD) onto glass-fibre filters. Radioactivity was measured with a Packard 2420 beta-spectrometer using Scint-A fluid (Packard, Downers Grove, IL). The lymph node cell stimulation index (SI) was calculated as net c.p.m. experimental/net c.p.m. control, i.e. (lymph node cells + test reagent)/(lymph node cells + culture medium only). For a given guinea-pig, the lymph node cell assay was considered positive when the SI was $>2.0$ at any of the concentrations tested. In addition to $\mathrm{G} 75 \mathrm{~m}$ at $12 \cdot 5-200 \mu \mathrm{g} / \mathrm{ml}$ final concentration, test reagents were preservativefree tuberculin-purified protein derivative (PPD-CT68 Lot A21: Connaugh Laboratories, Swiftwater, PA) at $6 \cdot 25-100 \mu \mathrm{g} / \mathrm{ml}$, and phyto-haemagglutinin $\mathrm{M}(10 \mathrm{mg} / \mathrm{ml}$ : Difco; Control No. 664780 ) at $1 / 2560$ to $1 / 160$ dilutions.

Peritoneal exudate cells. The direct assay for macrophage migration inhibitory factor (MIF) with peritoneal exudate cells was done in glass capillary tubes placed in leukocyte migration plates (Leu, Woodson \& Whitley, 1977). Four control wells (8 capillaries) filled with culture medium only were used, 2 at the start and 2 at the end of the set-up for a guinea-pig; each concentration of the test reagent occupied 2 wells. G75m was tested at $10-200 \mu \mathrm{g} / \mathrm{ml}$, and purified protein derivatives at 10 and $50 \mu \mathrm{g} / \mathrm{ml}$. The $24-\mathrm{h}$ migration patterns were projected to constant magnification, traced, and measured by planimetry. The cell migration index was calculated as 100 (mean area of migration in experimental wells/mean area in control wells). For each guinea-pig, the experimental areas were compared to its own control areas by Student's $t$ test. Macrophage migration was considered to be inhibited, or enhanced, significantly when the $P$ value was $<0.05$.

Assay of serum antibody against surface autoantigens on residual bodies, late spermatids and spermatozoa. The antibodies were measured as described by Han \& Tung (1979). 
Solid-phase radioimmunometric assay for antibody to $G 75 m$

Flat bottom, 96-well polystyrene microtitre plates (Dynatech Laboratories, Alexandria, VA) were coated with $\mathrm{G} 75 \mathrm{~m}, 25 \mu \mathrm{g}$ in $0.5 \mathrm{ml}$ per well. After drying by overnight storage at room temperature, the wells were washed three times with phosphate-buffered saline (PBS) containing $0.3 \%$ gelatin and $0.03 \%$ EDTA (RIA buffer). The test serum, $50 \mu$ diluted $1 / 20$ in PBS, was added to each well and incubated at room temperature for $3 \mathrm{~h}$. Each serum was tested in quadruplicate. The serum samples were removed, and the wells were washed 3 times with $150 \mu 1$ RIA buffer. After a fourth wash with $150 \mu \mathrm{l} 1 \% \mathrm{IgG}$-free bovine serum albumin (BSA) and a 5-min incubation with the same buffer, $0.02 \mu \mathrm{g}{ }^{125}$ I-labelled protein A in $50 \mu \mathrm{l}$ (about 100000 c.p.m.) was added to each well and incubated for $3 \mathrm{~h}$. The wells were washed 3 times with $150 \mu 11 \%$ IgG-free BSA, and were dried. The radioactivity of the well bottoms was determined in a gamma-spectrometer. A standard anti-G75m antiserum from guinea-pigs hyperimmunized with $\mathrm{G} 75 \mathrm{~m}$ produced a linear doseresponse curve in the dilution range of $1 / 64$ to $1 / 2$, with a well-bound radioactivity of $2000-10000$ c.p.m. Normal guinea-pig serum samples consistently showed anti-G75m activity of 1000-2000 c.p.m. For the experimental sera, anti-G75m activity was considered to be positive when the wellbound c.p.m. was $>3000$, and highly positive when $>5000$ c.p.m.

\section{Histopathology of the testes}

The testes were fixed in Zenker's fluid, embedded in paraffin wax, and $5 \mu \mathrm{m}$-thick semisequential sections were stained with periodic acid-Schiff's-haematoxylin (Putt, 1972). The absence or presence and type of pathology was assessed for the seminiferous tubules, rete testis, ductuli efferentes, and cauda epididymidis. A guinea-pig was considered to have allergic orchitis when inflammatory cellular infiltrates were found in one or more of the areas mentioned. The severity of the orchitis was assessed by the extent of cross-sectional areas infiltrated, the degree of infiltration, the presence (or absence) and extent of fibrosis, and the extent of aspermatogenesis.

\section{Experimental groups and statistical analyses}

A first group of guinea-pigs was immunized and tested with $\mathrm{G} 75 \mathrm{~m}$ pool A. Of these, 8 animals were killed 4 days after immunization, 14 at 7 days, 12 at 10 days, 14 at 14 days, 6 at 19 days and 4 at 29 days. Lymph node and peritoneal exudate cells were taken from 12 guinea-pigs, while the others were used for one or the other assay, since we noticed that i.p. injection of oil appeared to affect orchitis and the lymph node cell assay. To assess the effects of i.p. oil injection and to test for reproducibility of the immunogen, a second group of guinea-pigs was immunized with G75m pool B. This group comprised 8 animals killed 7 days after immunization (4 lymph node cell + peritoneal exudate cells), 24 at 10 days (12 for histopathology only, 8 for lymph node cell, 4 for peritoneal exudate cells) and 8 at 19 days (4 lymph node cells, 4 peritoneal exudate cells).

All statistical tests were done at $95 \%$ confidence level. For the analyses of incidences, guineapigs from different groups (+oil and - oil, pool A- and pool B-immunized) within a time period were combined when the $\chi^{2}$ test for homogeneity permitted it. Incidences were analysed by Fisher's Exact test, and by $\mathrm{G}$ and $\chi^{2}$ tests for independence when appropriate. Lymph node cell stimulation and peritoneal exudate cell migration indices were subjected to Analysis of Variance followed by Duncan's Multiple Range tests. The relationship between orchitis and the in-vitro assays was analysed by Kendall's Paired Rank Correlation (Campbell, 1974).

\section{Histopathology}

\section{Results}

The peak incidence of animals with histopathology occurred at Day 14 in guinea-pigs immunized with pool $\mathrm{A}$ of $\mathrm{G} 75 \mathrm{~m}$ antigen, and at Day 10 with pool B antigen (Table 1). Before and on Day 14 , orchitis occurred without aspermatogenesis in most guinea-pigs $(33 / 46,72 \%$, Table 2$)$. 
Table 1. Development of epididymo-orchitis, and of immune responses to $\mathrm{G} 75 \mathrm{~m}$ antigens in guinea-pigs immunized with G75m in Freund's complete adjuvant

\begin{tabular}{|c|c|c|c|c|c|c|c|}
\hline \multirow[b]{2}{*}{ Studies } & \multirow{2}{*}{$\begin{array}{l}\mathrm{G} 75 \mathrm{~m} \\
\text { antigen }\end{array}$} & \multicolumn{6}{|c|}{ Days after immunization } \\
\hline & & 4 & 7 & 10 & 14 & 19 & 29 \\
\hline \multirow[t]{2}{*}{ 1. Histopathology } & Pool A & $1 / 8(13 \%)$ & $4 / 14(29 \%)$ & $4 / 12(33 \%)$ & $12 / 14(86 \%)$ & $5 / 6(83 \%)$ & $4 / 4(100 \%)$ \\
\hline & Pool B & $*$ & $3 / 8(38 \%)$ & $22 / 24(92 \%)$ & $*$ & $8 / 8(100 \%)$ & $*$ \\
\hline \multirow[t]{2}{*}{$\begin{array}{l}\text { 2. MIF production } \\
\text { by PEC }\end{array}$} & Pool A & $\begin{array}{l}0 / 4 \\
100^{\mathrm{a}}\end{array}$ & $\begin{array}{l}1 / 4(25 \%) \\
46\end{array}$ & $\begin{array}{l}5 / 6(83 \%) \\
47 \pm 6.8\end{array}$ & $\begin{array}{l}5 / 7(71 \%) \\
33 \pm 2 \cdot 4\end{array}$ & $\begin{array}{l}3 / 4(75 \%) \\
53 \pm 5.0\end{array}$ & $0 / 2$ \\
\hline & Pool B & * & $\begin{array}{l}4 / 4(100 \%) \\
46 \pm 13\end{array}$ & $\begin{array}{l}4 / 4(100 \%) \\
18 \pm 4 \cdot 1\end{array}$ & * & $\begin{array}{l}4 / 4(100 \%) \\
35 \pm 15\end{array}$ & * \\
\hline \multirow[t]{2}{*}{$\begin{array}{l}\text { 3. LNC proliferative } \\
\text { response }\end{array}$} & Pool A & $\begin{array}{l}1 / 4(25 \%) \\
2 \cdot 1^{\mathrm{b}}\end{array}$ & $\begin{array}{l}6 / 9(67 \%) \\
6.6 \pm 1.6\end{array}$ & $\begin{array}{l}7 / 8(88 \%) \\
5.4 \pm 0.9\end{array}$ & $\begin{array}{l}4 / 6(67 \%) \\
3.5 \pm 0.7\end{array}$ & $\begin{array}{l}3 / 4(75 \%) \\
2 \cdot 5 \pm 0 \cdot 2\end{array}$ & $0 / 2$ \\
\hline & Pool B & * & $\begin{array}{l}5 / 7(71 \%) \\
5 \cdot 6 \pm 0.6\end{array}$ & $\begin{array}{l}8 / 8(100 \%) \\
5.7 \pm 0.8\end{array}$ & * & $\begin{array}{l}4 / 4(100 \%) \\
3.4(0.5)\end{array}$ & * \\
\hline \multirow[t]{2}{*}{$\begin{array}{l}\text { 4. Anti-TSDA } \\
\text { antibody }\end{array}$} & Pool A & $\begin{array}{l}2 / 6(33 \%) \\
11 \pm 2^{\mathrm{c}}\end{array}$ & $\begin{array}{l}2 / 4(14 \%) \\
11 \pm 1\end{array}$ & $\begin{array}{l}3 / 12(25 \%) \\
12 \pm 1 \cdot 5\end{array}$ & $\begin{array}{l}3 / 12(25 \%) \\
10 \pm 0 \cdot 4\end{array}$ & $\begin{array}{l}2 / 6(33 \%) \\
12 \pm 4.8\end{array}$ & $\begin{array}{l}1 / 4(25 \%) \\
9 \cdot 2\end{array}$ \\
\hline & Pool B & $*$ & $\begin{array}{l}3 / 7(43 \%) \\
16 \pm 5.9\end{array}$ & $\begin{array}{l}9 / 14(64 \%) \\
18 \pm 2 \cdot 6\end{array}$ & * & $\begin{array}{l}7 / 8(88 \%) \\
15 \pm 3 \cdot 4\end{array}$ & * \\
\hline \multirow[t]{2}{*}{$\begin{array}{l}\text { 5. Anti-G75m } \\
\text { antibody }\end{array}$} & Pool A & $\begin{array}{l}0 / 6 \\
-\end{array}$ & $\begin{array}{l}0 / 14 \\
-\end{array}$ & $\begin{array}{l}2 / 12(17 \%) \\
3016^{\mathrm{d}}\end{array}$ & $\begin{array}{l}4 / 12(33 \%) \\
3124\end{array}$ & $\begin{array}{l}3 / 6(50 \%) \\
3842\end{array}$ & $\begin{array}{l}4 / 4(100 \%) \\
5223\end{array}$ \\
\hline & Pool B & * & $0 / 7$ & $\begin{array}{l}4 / 14(29 \%) \\
3503\end{array}$ & * & $\begin{array}{l}5 / 8(63 \%) \\
5416\end{array}$ & * \\
\hline
\end{tabular}

MIF, macrophage migration inhibitory factor; PEC, peritoneal exudate cells; LNC, lymph node cells; TSDA, testicular cell/sperm differentiation autoantigens.

Values for the migration index ${ }^{(a)}$, stimulation index $^{(b)}$, and anti-TSDA antibody level ${ }^{(c)}(\mu g / m l$ serum) are mean \pm s.d.

(d) means c.p.m. values for guinea-pigs with positive anti-G75m antibody responses (normal range $=1000-2000$ c.p.m.).

* Not studied.

Table 2. Distribution of testicular histopathology in guinea-pigs immunized with G75m antigens (pool A or B)

Days after immunization

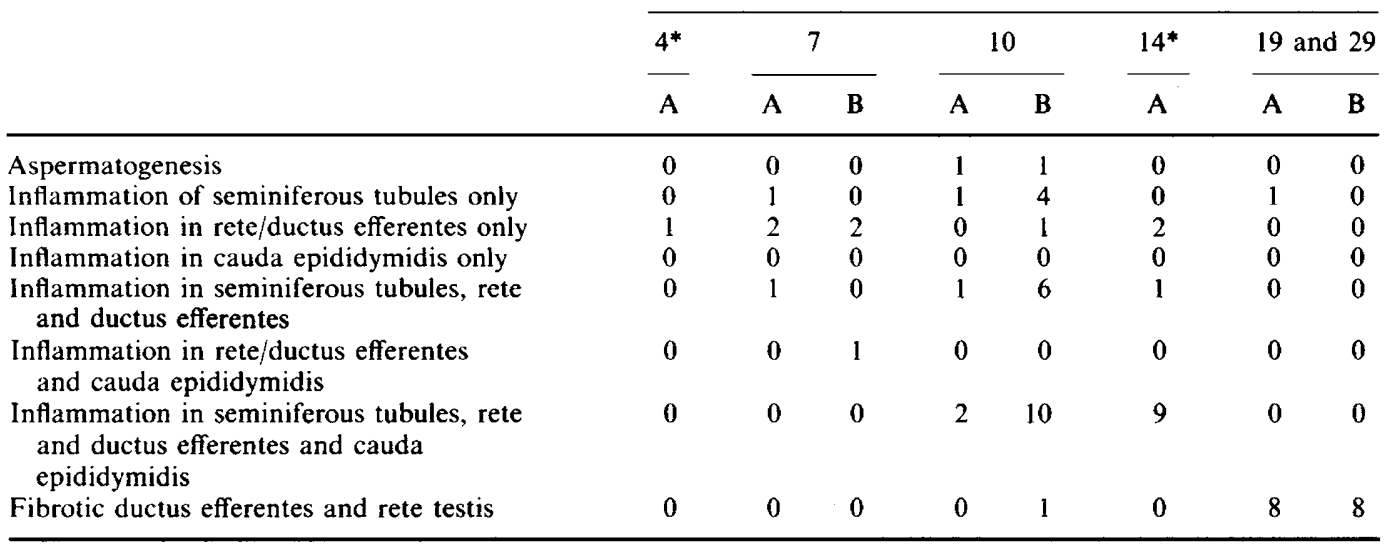

* Pool B antigen was not studied on these days.

Values are for no. of guinea-pigs; see text for no. of animals in each group. 
Aspermatogenesis alone occurred in only 2 of the 65 animals in the whole study. Early orchitis was found mainly in the rete testis and ductuli efferentes, although the seminiferous tubules and the cauda epididymidis were also involved by Day 10. However, in 6 of the 46 guinea-pigs (up to Day 14) orchitis was exclusively in the seminiferous tubules. Fibrosis occurred later after immunization.

Intraperitoneal injection of mineral oil at Day 7 reduced the incidence of orchitis at Day 10 in guinea-pigs immunized with pool A antigen $(P<0.05)$, but the frequency of orchitis on Day 7,14 or 19 was the same regardless of whether the guinea-pigs were injected with oil 3 days earlier (data not shown).

\section{Immune responses}

Prodiferative response of lymph node cells to $G 75 \mathrm{~m}$. The lymph node cells from unimmunized or adjuvant-immunized guinea-pigs were not stimulated by $\mathrm{G} 75 \mathrm{~m}$ to incorporate significant amounts of $\left[{ }^{3} \mathrm{H}\right]$ thymidine; the effects of immunization with G75m CFA are summarized in Table 1 (Study 3 ). The responses to $\mathrm{G} 75 \mathrm{~m}$ pool $A$ and pool $B$ antigens were similar. The incidence and magnitude were maximal by Day 7, and the magnitude declined from Day 10. The 2 animals studied on Day 29 were unresponsive.

Intraperitoneal injection of mineral oil at Day 4 significantly reduced the response of lymph node cells on Day $7(P=0.04)$ (data not shown).

Inhibition of peritoneal macrophage migration. The migration of peritoneal macrophages from unimmunized or adjuvant-immunized guinea-pigs was unaffected in the presence of $10-50 \mu \mathrm{g}$ G75m but was enhanced at higher doses. The incidence of response to pool A and pool B G75m was maximal at Day 10 and Day 7, respectively, while the magnitudes peaked at Days 14 and 10, and declined thereafter (Table 1, Study 2). The 2 guinea-pigs studied on Day 29 were unresponsive.

Anti-testicular cell surface antibody response. Our previous study established that the mean \pm s.d. level of antibody to testicular cell surfaces in normal adult male Hartley guinea-pigs was $3 \pm 2 \mu \mathrm{g} /$ $\mathrm{ml}$ (Tung, Bryson, Goldberg \& Han, 1979). In the present study, the mean +2 s.d. value was exceeded by 13 of $54(24 \%)$ guinea-pigs immunized with pool A antigen, and 19 of $29(66 \%)$ animals immunized with pool B antigen. Furthermore, the incidence of response of the latter animals increased significantly with time (Table 1, Study 4). However, the magnitude of antibody response did not differ between the two groups.

Anti-G75m antibody response. Guinea-pigs immunized with Freund's complete adjuvant did not develop anti-G75m antibody. Although a few of the $\mathrm{G} 75 \mathrm{~m}$-immunized animals had low levels of serum antibodies between Days 10 and 14, a higher proportion of animals studied on Days 19 and 29 were positive, and the antibody levels were higher (Table 1, Study 5). There was no association between positive responses for antigens to $\mathrm{G} 75 \mathrm{~m}$ and testicular cell surfaces; of 97 serum samples tested, $23 \%$ were positive only for the testicular cell surface antibody, while $12 \%$ were positive only for the $\mathrm{G} 75 \mathrm{~m}$ antibody. Consistently, the onset of cell-mediated immune responses preceded that of humoral antibody responses to $\mathrm{G} 75 \mathrm{~m}$. Maximum titres of anti-G75m antibodies were found in guinea-pigs in which the cellular immune response to $\mathrm{G} 75 \mathrm{~m}$ had subsided.

\section{Relationship of the immune responses to orchitis}

There was a consistent temporal relationship between the incidence and magnitude of cellular immure responses to $\mathrm{G} 75 \mathrm{~m}$ antigen and the development of orchitis. In guinea-pigs immunized 
with pool A antigen, the peak proliferative response of lymph node cells was on Day 7 , followed by peak incidences of peritoneal macrophage response on Day 10 and of orchitis on Day 14, when the magnitude of peritoneal macrophage response also peaked. The temporal relation between cellmediated immune responses and orchitis in guinea-pigs immunized with pool $\mathbf{B}$ antigen was similar, except that each of the indicators had an earlier onset (Table 1).

Table 3 summarizes the paired incidences of orchitis and cell-mediated immune responses to G75m antigen in individual guinea-pigs. Animals immunized with pool A or pool B antigens were studied together. Guinea-pigs without orchitis but exhibiting a positive or a negative proliferative response of lymph node cells belonged exclusively to animals studied before Day 14. Guinea-pigs with orchitis and a negative lymph node cell response clustered in the period beyond Day 10. Although a similar pattern pertained to the orchitis/migration inhibition factor, several guinea-pigs studied early after immunization had orchitis in the absence of MIF responsiveness (Table 3, last column).

Table 3. Paired incidences for orchitis and lymph node cell (LNC) proliferative assay or macrophage migration inhibitory factor (MIF) assay as a function of time after immunization

\begin{tabular}{|c|c|c|c|c|c|c|c|c|c|c|c|}
\hline \multirow[b]{2}{*}{ Day } & \multirow{2}{*}{$\begin{array}{c}\mathrm{G} 75 \mathrm{~m} \\
\text { pool }\end{array}$} & \multirow{2}{*}{$\begin{array}{c}\text { No. of } \\
\text { animals }\end{array}$} & \multicolumn{4}{|c|}{ Orchitis/LNC proliferative assay } & \multirow{2}{*}{$\begin{array}{c}\text { No. of } \\
\text { animals }\end{array}$} & \multicolumn{4}{|c|}{ Orchitis/MIF assay } \\
\hline & & & $-1-$ & $-1+$ & $+1+$ & $+1-$ & & $-1-$ & $-1+$ & $+1+$ & $+1-$ \\
\hline 4 & A & 4 & 1 & 3 & & & 4 & 3 & & & 1 \\
\hline \multirow[t]{2}{*}{7} & A & 9 & 3 & 3 & 3 & & 4 & 2 & 1 & & 1 \\
\hline & B & 7 & 1 & 4 & 2 & & 4 & & 3 & 1 & \\
\hline \multirow[t]{2}{*}{10} & A & 8 & 2 & 3 & 3 & & 6 & & 5 & & 1 \\
\hline & B & 8 & & 1 & 7 & & 4 & & 1 & 3 & \\
\hline 14 & A & 6 & & & 4 & 2 & 7 & 1 & & 5 & 1 \\
\hline \multirow{2}{*}{19} & A & 4 & & & 3 & 1 & 4 & 1 & & 3 & \\
\hline & B & 4 & & & 4 & & 4 & & & 4 & \\
\hline 29 & A & 2 & & & & 2 & 2 & & & & 2 \\
\hline $\begin{array}{l}\text { Total } \\
(\%)\end{array}$ & & 52 & $\begin{array}{c}7 \\
(13 \%)\end{array}$ & $\begin{array}{c}14 \\
(27 \%)\end{array}$ & $\begin{array}{c}26 \\
(50 \%)\end{array}$ & $\begin{array}{c}5 \\
\left(10^{\circ} \%\right)\end{array}$ & 39 & $\begin{array}{c}7 \\
\left(18^{\circ} \%\right)\end{array}$ & $\begin{array}{c}10 \\
\left(26^{\circ} \%\right)\end{array}$ & $\begin{array}{c}16 \\
(41 \%)\end{array}$ & $\begin{array}{c}6 \\
(15 \%)\end{array}$ \\
\hline
\end{tabular}

The relationships between severity of orchitis and magnitude of cellular immune responses to G75m antigen were analysed in guinea-pigs that were positive in both variables. Irrespective of which time periods were analysed, alone or together (Days 7 and 10; Days 10 and 14; Days 14 and 19; Day 19), there was a positive, although not always significant, correlation between orchitis and proliferative responses of lymph node cells. The relationship between increasing severity of orchitis and increasing responsiveness of peritoneal macrophages was such that a negative correlation characterized the period Days 7 to $14(\tau=-0.5, \mathrm{~S}=-21, n=9)$, whereas a positive correlation $(\tau=+0 \cdot 81, \mathrm{~S}=+17, n=7)$ existed for guinea-pigs studied after Day 14 .

\section{Discussion}

Several findings prompted this study of cell-mediated immune response and humoral antibody response to sperm antigens as possible correlates to experimental allergic orchitis. Vasectomy in the rabbit led to immune complex orchitis (Bigazzi, Kosuda, Hsu \& Andres, 1976), with lesions resembling those that are transferrable by guinea-pig lymphoid cells to syngeneic recipients (Tung, 1978). Although orchitis has not been detected in men after vasectomy, this possibility has not been ruled out. Likewise, testicular autoimmunity has not been excluded as a cause of the high frequency of infertility observed in men following vasovasostomy (Linnet \& Hjort, 1980). It is, therefore, important to develop an in-vitro test indicative of testicular autoimmune disease. A study of testis biopsies from infertile men revealed evidence of immunological mechanisms in the form of 
immune complexes (Solamon, Saremaslani, Jakob \& Hedinger, 1982). Since experimental autoimmune orchitis appears to be a disease caused mainly by cell-mediated mechanisms, it is important to study infertile men, and perhaps women, for cell-mediated immune responses to sperm antigens.

It is known that spermatozoa and testis tissue possess numerous autoantigens, not all of which are capable of inducing allergic orchitis (Hagopian et al., 1976). Correlative studies between cellmediated immune responses to spermatozoa and orchitis are only meaningful if antigen(s) relevant to induction of the disease are used. The potent aspermatogenic protein, AP3, is the only detectable aspermatogenic antigen in an extracted, delipidated preparation of guinea-pig testicular proteins with a molecular weight between 15000 and $30000(\mathrm{G} 75 \mathrm{~m}$ ) (Teuscher et al., 1983b). In this study, we used two in-vitro methods to evaluate the cell-mediated immune responses to $\mathrm{G} 75 \mathrm{~m}$ of guineapigs immunized with $\mathrm{G} 75 \mathrm{~m}$, and examined their relationship to humoral antibody responses to sperm antigens, and to the development of orchitis. The results demonstrated a convincing temporal pattern of cell-mediated immune responses in relation to orchitis development. Antigeninduced specific proliferation of lymph node cells was detected as early as 4 days after immunization. This was followed 3 days later by the maximum lymph node cell response, which was followed by maximum antigen-induced secretion of migratory inhibitory factor by peritoneal exudate cells when lesions of orchitis became manifest. This sequence of immunopathological events was reproducible even when two different preparations of $\mathrm{G} 75 \mathrm{~m}$ antigens were used. While the three biological events occurred earlier in guinea-pigs immunized with pool B antigen, the order in which these events were manifest remained the same. These findings indicate that $\mathrm{G} 75 \mathrm{~m}$ reactive lymphocytes were present within the regional lymph nodes within 4 days after induction of orchitis. These cells soon circulated and could be attracted to the inflammatory reaction induced by oil in the peritoneal cavity.

The nature of the relationship between orchitis and cell-mediated immune response to $\mathrm{G} 75 \mathrm{~m}$ in individual animals was dissimilar for the peritoneal exudate and lymph node cells. The magnitude of the proliferative response of lymph node cells showed positive correlation with severity of active testicular disease. In contrast, the peritoneal exudate cells obtained on or before Day 14 produced less migration inhibitory factor when the orchitis was more severe.

In contrast to cell-mediated immune responses, humoral antibodies to $\mathrm{G} 75 \mathrm{~m}$ or to cell surface antigens of testicular cells bore no correlative relationship to the presence of orchitis. Thus, peak antibody levels were detected at a time when cell-mediated immune responses had subsided, and when the active phase of the disease had waned. The data from this study support the suggestion that orchitis in the guinea-pig is an immunological disease induced mainly by cell-mediated immune mechanisms. Additional evidence for this derives from a number of observations. First, the histopathology of orchitis is that of cell-mediated immunological injury (Waksman, 1959; Tung, Unanue \& Dixon, 1970). Second, the orchitic lesions can be transferred locally (Tung et al., 1971a; Kantor \& Dixon, 1972) and systemically (Carlo et al., 1976) with lymphoid cells, or with enriched T lymphocytes (Tung, Leong \& McCarty, 1977). In contrast, focal disease can be transferred with difficulty by immune sera, and recipients had to receive Freund's complete adjuvant before the disease is induced (Tung et al., 1971b; Toullet \& Voisin, 1976). Third, murine orchitis cannot be induced in nude mice, but can be induced in nude mice reconstituted with thymic cells from their $+/$ nu littermates (Bernard, Mitchell, Leydon \& Bargerbos, 1978). Also, studies on the antigen AP3 have shown that it retains its aspermatogenic property after reduction and alkylation, suggesting a role for amino acid sequential antigen determinant, and not conformation determinant, in disease induction (Teuscher et al., 1983b). Gell \& Benacerraf (1959) have provided evidence that sequence antigenic determinants elicit mainly cell-mediated immune responses.

There have been several studies on the cell-mediated immune responses to sperm antigens in guinea-pigs with orchitis (Freund, Thompson \& Lipton, 1955; Baum, Baughton, Mongar \& Schild, 1961 ; Brown, Glynn \& Holborow, 1967; Voisin \& Toullet, 1969; Mazzolli, 1971; Marcus, Nebel, Soffer, Stahl \& Toullet, 1975; Muir \& Turk, 1979; Hojo, Hiramine \& Ishitaki, 1980). Taken 
together, these studies provide evidence for an overall association between positive cell-mediated immune responses and orchitis. Hojo et al. (1980) studied the response of lymph node cells in guinea-pigs to an antigenic preparation that probably contained $675 \mathrm{~m}$ and detected an initial peak of cell-mediated immune response, followed by a second peak after active testicular disease had completely subsided. In our study and that by Hojo et al. (1980) decline of active orchitis was associated with diminution of cell-mediated immune responses. Whether this results from the activity of suppressor cells or suppressor factors needs further investigation. It is possible that the second peak of cell-mediated immune response detected by Hojo et al. (1980) represents immune response to endogenous antigens released from the diseased testes. Earlier studies (Brown et al., 1967; Voisin, 1982) based on different antigenic preparations have led to the conclusion that both cell-mediated immunity and humoral antibodies might be involved in the pathogenesis of allergic orchitis.

The findings in this study of (1) the effect of oil-induced peritoneal exudate on the cell-mediated immune response of lymph node cells and on the time of onset of orchitis, and (2) the negative correlation between orchitis and response to migration factors early after disease induction are consistent with preferential recruitment of recently activated $\mathrm{T}$ lymphocytes into inflammatory sites (Koster, McGregor \& Mackaness, 1971; Asherson, Allwood \& Mayhew, 1973; McGregor \& Logie, 1974) and competition for these cells by different inflammatory loci. Treatment with oil may therefore reduce the number of antigen-reactive cells in the lymph nodes, and in the circulating pool capable of orchitis induction. Care should therefore be taken when the same animal is used to assess different aspects of cell-mediated immune responses, inasmuch as the experimental manipulation required for one study may significantly influence the other, including manifestation of disease.

We thank Dr Bebe Han and Dr Cory Teuscher for providing us with the G75m antigens used in this study; Dr Dorothy Pathak and Jepthah Choate for statistical help; Jean Hu for assistance with lymph node cell assays; and Joanne Migneault for preparation of the manuscript. Cory Teuscher developed the antibody assay to $\mathrm{G} 75 \mathrm{~m}$; and the antibody assays were carried out by George Montoya and Kathleen Baldwin. This study is supported by grants (HD-14045 and HD-12247) from the National Institutes of Health.

\section{References}

Asherson, G.L., Allwood, G.G. \& Mayhew, B. (1973) Contact sensitivity in the mouse. XI. Movement of T lymphoblasts in the draining lymph nodes to sites of inflammation. Immunology 25, 485-494.

Baum, J., Baughton, B., Mongar, J.L. \& Schild, H.O. (1961) Autosensitization by sperm in guinea pig. Immunology 4, 95-110.

Bernard, C.C.A., Mitchell, G.F., Leydon, J. \& Bargerbos, A. (1978) Experimental autoimmune orchitis in Tcell-deficient mice. Int. Archs Allergy appl. Immun. 56, 256-263.

Bigazzi, P.E., Kosuda, L.L., Hsu, K.C. \& Andres, G.A. (1976) Immune complex orchitis in vasectomized rabbits. J. exp. Med. 143, 382-404.

Brown, P.C., Glynn, L.E. \& Holborow, E.J. (1967) The dual necessity for delayed hypersensitivity and circulating antibody in the pathogenesis of experimental allergic orchitis in guinea-pigs. Immunology 13, 307-314.

Campbell, R.C. (1974) Statistics for Biologists, p. 100. Cambridge University Press.
Carlo, D.J., Hagopian, A., Jackson, J.J., Limjuco, G.A. \& Eylar, E.H. (1976) Experimental allergic orchitis and aspermatogenesis. VI. Transfer of allergic orchitis with immune cells. J. Immun. 116, 619-622.

Freund, J., Lipton, M.M. \& Thompson, G.E. (1953) Aspermatogenesis in the guinea-pig induced by testicular tissue and adjuvant. J. exp. Med. 97, 711725.

Freund, J., Thompson, G.E. \& Lipton, M.M. (1955) Aspermatogenesis, anaphylaxis and cutaneous sensitization induced in the guinea-pig by homologous testicular extract. J. exp. Med. 101, 591-603.

Gell, P.G.H. \& Benacerraf, B. (1959) Studies on hypersensitivity. II. Delayed hypersensitivity to denatured proteins in guinea pigs. Immunology 2, 6470.

Hagopian, A., Jackson, J.J., Carlo, D.J., Limjuco, G.A. \& Eylar, E.H. (1975) Experimental allergic aspermatogenic orchitis. III. Isolation of spermatozoal glycoproteins and their roles in allergic aspermatogenic orchitis. J. Immun. 115, 1731-1743. 
Hagopian, A., Limjuco, G.A., Jackson, J.J., Carlo, D.J. \& Eylar, E.H. (1976) Experimental allergic aspermatogenic orchitis. IV. Chemical properties of sperm glycoproteins isolated from guinea pig testes. Biochim. Biophys. Acta 434, 354-364.

Han, L.-P.B. \& Tung, K.S.K. (1979) A quantitative assay for antibodies to surface antigens of guinea pig testicular cells and spermatozoa. Biol. Reprod. 21, 99107.

Hojo, K., Hiramine, C. \& Ishitaki, M. (1980) Lymphocyte proliferative response in vitro and its cellular dependency in guinea-pigs with experimental allergic orchitis. J. Reprod. Fert. 59, 113-123.

Jackson, J.J., Hagopian, A., Carlo, D.J., Limjuco, G.A. \& Eylar, E.H. (1975) Experimental allergic aspermatogenic orchitis. I. Isolation of a spermatozoal protein (AP1) which induced allergic aspermatogenic orchitis. J. biol. Chem. 250, 6141-6150.

Jackson, J.J., Hagopian, A., Carlo, D.J., Limjuco, G.A. \& Eylar, E.H. (1976) Experimental allergic aspermatogenic orchitis. II. Some chemical properties of the APl protein of the sperm acrosome. Biochim. Biophys. Acta 427, 251-261.

Kantor, G.L. \& Dixon, F.J. (1972) Transfer of experimental allergic orchitis with peritoneal exudate cells. J. Immun. 108, 329-338.

Koster, F.T., McGregor, D.D. \& Mackaness, G.B. (1971) The mediator of cellular immunity. II. Migration of immunologically committed lymphocytes into inflammatory exudates. $J$. exp. Med. 133, 400-409.

Leu, R.W., Woodson, P.D. \& Whitley, S.B. (1977) Role of macrophage activation on the response to migration inhibitory factor (MIF). J. Reticuloendothel. Soc. 22, 329-340.

Linnet, L. \& Hjort, T. (1980) Association between failure to impregnate after vasovasostomy and sperm agglutinins in semen. Lancet i, 117-119.

Marcus, Z.H., Nebel, L., Soffer, Y., Stahl, Y. \& Toullet, F. (1975) Studies on sperm antigenicity. 2. In vivo and in vitro cellular reactivity in guinea pigs sensitized to homologous and heterologous spermatozoal autoantigens. Fert. Steril. 26, 1024-1034.

Mazzolli, A.B. (1971) Demonstration in vitro of delayed hypersensitivity in experimental allergic orchitis in guinea-pigs. J. Reprod. Fert. 26, 161-166.

McGregor, D.D. \& Logie, P.S. (1974) The mediator of cellular immunity. VII. Localization of sensitized lymphocytes in inflammatory exudates. J. exp. Med. 139, 1415-1430.

Muir, V.Y.\& Turk, J.L. (1979) Immunological unresponsiveness during induction of experimental autoimmune orchitis in guinea pig: studies in vivo and in vitro. Immunology 36, 95-102.

Parish, C.R., Kirov, S.M., Bowern, N. \& Blanden, R.V. (1974) A one-step procedure for separating mouse $T$ and B lymphocytes. Eur. J. Immun. 4, 803-815.

Putt, F.A. (1972) Manual for Histological Staining Methods, p. 66. Wiley and Sons, New York.

Roos, D. \& Loos, J.A. (1970) Changes in the carbohydrate metabolism of mitogenically stimulated human peripheral lymphocytes. Biochim. Biophys. Acta 222, $565-582$.

Solamon, F., Saremaslani, P., Jakob, M. \& Hedinger, C.E. (1982) Immune complex orchitis in infertile men. Immunoelectron microscopy of abnormal basement membrane structures. Lab. Invest. 47, 555-567.

Teuscher, C., Wild, G.C. \& Tung, K.S.K. (1983a) Acrosomal autoantigens of guinea pig sperm. I. The purification of an aspermatogenic protein, AP2. $J$. Immun. 130, 317-322.

Teuscher, C., Wild, G.C. \& Tung, K.S.K. (1983b) Experimental allergic orchitis. The isolation and partial characterization of an aspermatogenic polypeptide (AP3) with an apparent sequential diseaseinducing determinant(s). J. Immun. 130, 2683-2688.

Toullet, F. \& Voisin, G.A. (1976) Passive transfer of autoimmune aspermatogenic orchiepididymitis (AIAO) by antispermatozoa serum. Influence of the type of autoantigen and of the class of antibody. Clin. exp. Immunol. 26, 549-562.

Tung, K.S.K. (1978) Allergic orchitis lesions are adoptively transferred from vasoligated guinea pigs to syngeneic recipients. Science, N.Y. 201, 833 835.

Tung, K.S.K., Unanue, E.R. \& Dixon, F.J. (1970) The immunopathology of experimental allergic orchitis. Am. J. Path. 60, 313-324.

Tung, K.S.K., Unanue, E.R. \& Dixon, F.J. (1971a) Pathogenesis of experimental allergic orchitis. I. Transfer with immune lymph node cells. $J$. Immun. 106, 1453-1462.

Tung, K.S.K., Unanue, E.R. \& Dixon, F.J. (1971b) Pathogenesis of experimental allergic orchitis. II. The role of antibody. J. Immun. 106, 1463-1472.

Tung, K.S.K., Leong, C. \& McCarty, T. (1977) Pathogenesis of experimental allergic orchitis. III. T lymphocyte requirement in local adoptive transfer of peritoneal exudate cells. J. Immun. 118, 1774-1779.

Tung, K.S.K., Bryson, R., Goldberg, E. \& Han, L.-P.B. (1979) Antisperm antibody in vasectomy: studies in human and guinea pig. In Vasectomy: Immunologic and Pathophysiologic Efforts in Animals and Man, pp. 267-284. Eds I. H. Lepow \& R. Crozier. Academic Press, New York.

Voisin, G.A. (1982) Sperm specific autoantigens. In Immunological Factors in Human Reproduction, pp. 147-161. Eds S. Shulman, F. Dondero \& M. Nicotra. Academic Press, London.

Voisin, G.A. \& Toullet, F. (1969) Relation between hypersensitivity responses to autoantigens and tissue damage in the male reproductive tract. In Immunology and Reproduction, pp. 93-106. Ed. R. G. Edwards. International Planned Parenthood Federation, London.

Voisin, G.A., Delaunay, A. \& Barber, M. (1951) Lesions testiculaires provoquees chez le cobaye par injection d'extrait de testicule homologue. C. $r$. hebd. Séanc. Acad. Sci., Paris D 232, 1264-1266.

Waksman, B.H. (1959) A histologic study of the autoallergic testis lesion in the guinea-pig. J. exp. Med. 109, 311-324. 